\title{
Ścieranie się ze zdrowym rozsądkiem i latanie dziur kulturowych. Kultura filozofii u Leszka Nowaka i Józefa Niżnika
}

\author{
Krzysztof Abriszewski \\ Instytut Filozofii \\ Uniwersytet Mikołaja Kopernika w Toruniu \\ krzabr@umk.pl \\ Przyjęto: październik 2017; zaakceptowano: grudzień 2017.
}

\begin{abstract}
Abstrakt
W artykule stawiam pytanie o kulturową funkcję filozofii oraz filozofowania i analizuję metafilozofię Leszka Nowaka i Józefa Niżnika, interpretując je jako kulturę filozofii. To znaczy redefiniuję ogólne cechy filozofii, wskazane przez Nowaka i Niżnika w ich analizach metafilozoficznych, jako względnie powszechnie podzielane przez filozofów założenia na temat ich dyscypliny. Tego rodzaju redefinicja filozofii jako gry kulturowej pozwala zapytać w dalszej kolejności o to, jakiego rodzaju poznawczą grą kulturową jest filozofia. Aby odpowiedzieć na to pytanie, stosuję model czterech typów poznania Andrzeja Zybertowicza, który wyróżnia odtwarzanie, odkrywanie, redefiniowanie oraz projektowanie gier kulturowych. Na koniec tekstu podążam za tezą Niżnika mówiącą, że funkcja filozofii polega na uspójnianiu uniwersum symbolicznego w sytuacjach jego naruszenia (co nazywam dziurami ontologicznymi) i przedstawiam dwa przykłady z historii filozofii rozpoznania tego rodzaju naruszenia, które następnie uzyskało filozoficzną konceptualizację.
\end{abstract}

Słowa kluczowe: filozofowanie; metafilozofia; kultura filozofii; zdrowy rozsądek; uspójnianie kultury; dziury ontologiczne; ludzkie uniwersum symboliczne 


\section{Wprowadzenie}

Niniejszy tekst stanowi część szerszego projektu¹, w którym skoncentrowałem się na zagadnieniu kulturowych funkcji filozofowania. Wyszedłem od pytania o funkcje filozofii w kulturze, ale dość szybko okazało się, że takie postawienie sprawy może rzecz bardziej komplikować. Z dwóch powodów. Po pierwsze, mówienie o „filozofii” sugerowało rolę określonych treści w szerszym kontekście kulturowym. Po drugie, mówienie o „filozofii” przyciągało jak magnes niechciany problem demarkacji: co jest, a co nie jest filozofią? Tymczasem „filozofowanie” usuwało obie komplikacje - dokładnie odpowiadało na mojej intencji skoncentrowania się na praktykach filozoficznych, a nie na gotowych treściach - wszak sami filozofowie często bronią tezy, że ważniejsze niż określone treści uzyskane na końcu całego procesu jest sproblematyzowanie zagadnienia (postawienie pytania), albo sposób argumentacji (czyli droga). Nie ulega również wątpliwości, że filozofia pojmowana jako zasób określonych treści koniec końców słabo wypada w konkurencji z nauką. Oczywiście doskonale wiemy, że filozofowie, przynajmniej niektórzy, również z tym kłopotem starają się jakoś sobie radzić, mówiąc na przykład, że filozofia od zawsze stawia innego rodzaju pytania niż nauki empiryczne, albo argumentując w duchu Odo Marqarda, który nazywa filozofa „kaskaderem eksperta” (Marquard, 1994, s.39-67), że filozofia może pozwolić sobie na spekulacje tam, gdzie nauka jeszcze nie potrafi dotrzeć. Posłużenie się słowem „filozofowanie” rozwiązywało problem dlatego, że miało szeroki, inkluzywny charakter, obejmując również takie jak to stanowiska. Po drugie, uchylało kwestię demarkacji - mowa była o pewnych działaniach, a nie tylko określonej dyscyplinie.

Projekt mój realizowałem dwutorowo. Pierwszy zakres pracy, prowadzonej na mniejszą skalę, wiązał się z analizą wybranych wywodów metafilozoficznych $\mathrm{z}$ intencją zreinterpretowania ich $\mathrm{w}$ taki sposób, żeby mówiły o filozofii jako o grze kulturowej ulokowanej w kontekście innych gier kulturowych. Uznałem jednak, że to podejście nie jest wystarczające, choćby dlatego, że ograniczało się ono w punkcie wyjścia do perspektywy samych filozofów, nawet jeśli dalej była ona przekształcana. Toteż drugi zakres mojej pracy wiązał się z opracowaniem szerszego kulturoznawczego modelu, który pokazywałby jak filozofowanie wygląda w działaniu. Aby jednak nie osunąć się do poziomu ogólnikowych

\footnotetext{
${ }^{1}$ Artykuł bazuje na fragmentach mojej książki Kulturowe funkcje filozofowania, opublikowanej w roku 2013 przez Wydawnictwo Naukowe Uniwersytetu Mikołaja Kopernika w Toruniu. Zostały one przeredagowane tak, aby utworzyć jednolitą, sensowną całość: usunąłem partie tekstu, które nadmiernie opierały się na kontekście książki i były poza nim niezrozumiałe, pozostawiłem jednak kilka odnośników do reszty książki tam, gdzie nie psuło to wywodu i zasadniczo działało analogicznie jak zwyczajne przypisy do literatury w tekście. Dodałem znaczną część wprowadzającą i wyjaśniającą oraz przeredagowałem miejsca połączeń fragmentów. Następujące fragmenty książki wykorzystałem w przygotowaniu niniejszego tekstu: z Części I: rozdz. 3: „Narzędzie ostatnie - Wallerstein i kultura filozofii”, s. 79-81, rozdz. 6: „Przeciw zdrowemu rozsądkowi - Leszek Nowak”, s. 105117, rozdz. 7: „Funkcja i status - Józef Niżnik”, s. 119-128, „Podsumowanie”, s. 129-132, z Części II: „Wprowadzenie”, s. 139-142. Zostały one przedrukowane za zgodą Wydawcy, za którą dziękuję. Dziękuję również redakcji Avantu za wyrażenie zainteresowania moją pracą.
} 
uwag, w książce (Abriszewski, 2013) posłużyłem się materiałem empirycznym w postaci życia i twórczości filozoficznej Barucha Spinozy, które powiązałem w jedno za pomocą kategorii rzeczywistości życia codziennego.

Niniejszy artykuł przedstawia część dociekań z pierwszego zakresu i obejmuje krótkie przedstawienie dwóch narzędzi teoretycznych, które wykorzystuję do kulturoznawczej reinterpretacji tez metafilozoficznych, analizę dwóch wybranych stanowisk - Leszka Nowaka i Józefa Niżnika - stanowiącą zasadniczą część tekstu oraz moment przejścia do drugiego zakresu dociekań wykorzystujący argumentację Niżnika. Dzięki temu Czytelnik/Czytelniczka będzie miał/a wgląd $w$ to, co robiłem $w$ ramach pierwszego zakresu działań, ale również sygnał, co działo się w drugim.

\section{Model 4 typów poznania}

Metafilozoficzne wywody Leszka Nowaka i Józefa Niżnika, czyli fragmenty, odpowiednio, pierwszego tomu Bytu i myśli (Nowak, 1998) oraz Arbitralność filozofii (Niżnik, 1999), chciałbym przeczytać przez filtr dwóch narzędzi interpretacyjnych, które pokrótce omówię. Pierwszym z nich są cztery typy poznania wyróżnione przez Andrzeja Zybertowicza (1995, s. 127-152), na drugie składają się uwagi Immanuela Wallersteina na temat kultury danej dyscypliny naukowej - sam Wallerstein odnosi się bezpośrednio do socjologii (Wallerstein, 2004, s. 262-308). Zostaną one przedstawione w następnej części artykułu.

Zybertowicz wyodrębnia cztery typy poznania, przyjmując perspektywę, w której jest ono grą kulturową. Jej przedmiotem jest wiedza, którą kultura musi wytwarzać, ale również transmitować i reprodukować, aby jako całość mogła dalej istnieć. Jedną z zalet tego podejścia jest kontekstualizacja wiedzy, inaczej niż w wielu uproszczonych modelach epistemologicznych nie jest ona już kwestią swego rodzaju gry między podmiotem i przedmiotem poznania. Inna zaleta kryje się właśnie w tej kontekstualizacji - jeśli potraktujemy to, co się dzieje $\mathrm{z}$ wiedzą, jako procesy kulturowe, to również filozoficzny namysł nad nimi stanie się częścią gier kulturowych. Nie chodzi wcale o hipotetyczny zarzut, jakoby ktokolwiek kiedykolwiek twierdził, że nie należą one do kultury, lecz o zwyczajne przesunięcie akcentów - w tej optyce procesy związane $\mathrm{z}$ wiedzą i filozofia będą interesujące przede wszystkim jako operacje kulturowe.

Wyróżnione w tym modelu typy poznania to:

Typ 1 - odtwarzanie - tego rodzaju procesy poznania opierają się na reprodukcji wiedzy istniejącej. Najbardziej paradygmatycznym przykładem jest nauka szkolna, mająca na celu nauczenie uczniów tego, co zostało ustabilizowane jako wiedza (por. Zybertowicz, 1995, s. 128-129). 
Typ 2 - odkrywanie - nawiązując do chętnie przywoływanego przez Slavoja Žižka momentu z lutego 2002 roku, w którym członek amerykańskiej administracji, Donald Rumsfeld, komentując relacje z Irakiem uciekł się do operacji filozoficznych, można powiedzieć, że odkrywanie jest tym, co umknęło wtedy Rumsfeldowi (Žižek, 2014, s. 8-9). Przypomnijmy, wyróżnił on znane znane czyli to, co wiemy, że wiemy; znane nieznane - czyli to, o czym wiemy, że nie wiemy oraz nieznane nieznane - czyli coś, o czym nawet nie wiemy, że nie wiemy. Brakującym elementem jest oczywiście nieznane znane, czyli to, o czym nie wiemy, że wiemy. Otóż z odkrywaniem mamy do czynienia wtedy, gdy wydobywamy wiedzę „ukrytą” w istniejących grach kulturowych. Charakterystycznym przykładem będzie operowanie na big data po to, by z olbrzymiej bazy danych wyłowić korelacje, które już istniały i na temat których już zebraliśmy informacje, ale których jeszcze nie zamieniliśmy w wiedzę. Czekały one niejako na stworzenie stosownej procedury, która przeniesie je $\mathrm{z}$ „nieznanych” do „znanych”. Analogię tę możemy rozciągnąć i potraktować ogół gier kulturowych jako gigantyczną bazę danych - pojawienie się nowych praktyk i ich stabilizacja, np. nowa emigracja, także stanowi sytuację, w której już istnieją określone gry kulturowe, ale nie zostały one jeszcze naukowo czy teoretycznie skonceptualizowane (por. Zybertowicz, 1995, s. 129-141).

Typ 3 - redefiniowanie - są to procesy, które polegają na redefiniowaniu kształtu istniejących już gier kulturowych. O ile odkrywanie zgłębia istniejące gry kulturowe $\mathrm{w}$ tej formie, $\mathrm{w}$ jakiej one istnieją, redefiniowanie zmienia ich reguły. Jest więc $\mathrm{w}$ gruncie rzeczy ingerencją $\mathrm{w}$ świat, aktem konstruowania, a nie odzwierciedlania. Tutaj możemy przywołać wszystkie te innowacje kulturowe, które nadały nowy bieg obszarowi, w ramach którego się pojawiły: rock'n'roll jako nowa forma doświadczania muzyki, telefony komórkowe wraz $\mathrm{z}$ Internetem jako nowa forma kontaktów z innymi ludźmi itd. (por. Zybertowicz, 1995, s. 141-148).

Typ 4 - projektowanie - oznacza ono projektowanie nowych obszarów doświadczenia kulturowego, już nie rozpoznawanie istniejących gier (odkrywanie) ani ich przetwarzanie, zmienianie ich ram (redefiniowanie), ale wytwarzanie nowych ram, czy nowych przestrzeni (por. Zybertowicz, 1995, 148-151).

Mając do dyspozycji ten czteroelementowy model ${ }^{2}$, można zadać proste pytanie wywodom metafilozoficznym: jakiego rodzaju formy poznania widzą one w filozofii, jeśli nałożyć na nie przedstawiony właśnie model? Innymi słowy: jeśli filozofowie sami opisują swoje działania w formie ujęć metafilozoficznych, to jakiego rodzaju ruchami są one w grach kulturowych?

\footnotetext{
${ }^{2}$ Ma on pewne swoja słabości, które szerzej omawiam w książce.
} 


\section{Wallerstein i kultura filozofii}

W niezwykle interesującym tekście „Dziedzictwo socjologii, obietnica nauki społecznej”, który wieńczy książkę Immanuela Wallersteina Koniec świata jaki znamy, autor rozpoczyna uwagi na temat wyzwań stojących przed współczesną socjologią, naukami społecznymi i w zasadzie strukturami wiedzy naukowej w ogóle od wskazania trzech perspektyw na wiedzę naukową oraz zdefiniowania czegoś, co nazywa „kulturą socjologii” (Wallerstein, 2004, s. 262-307).

Pisze on mianowicie tak:

Zwykliśmy dzielić wiedzę na trzy różne sposoby: intelektualnie na dyscypliny, organizacyjnie na struktury korporacyjnie, i kulturalnie na wspólnoty uczonych podzielających pewne podstawowe założenia (Wallerstein, 2004, s. 262).

Perspektywa intelektualna (dyscypliny) wskazuje zakres i metody działań danej dziedziny, perspektywa organizacyjna (struktury korporacyjne) skupia się na instytucjonalnej dynamice danej dziedziny (Wallerstein, 2004, s. 262263). Nas jednak interesować będzie ujęcie kulturowe, wskazujące na założenia podzielane przez daną wspólnotę uczonych. Oto, w jaki sposób kulturę uczonych pojmuje amerykański socjolog:

przez „kulturę” zwykle rozumiemy zestaw podzielanych założeń i praktyk, podzielanych wprawdzie nie przez wszystkich członków społeczności i nie zawsze, lecz przez większość z nich przez większość czasu. Podzielanych otwarcie, ale, co jeszcze ważniejsze, podzielanych podświadomie, tak, że owe założenia rzadko są przedmiotem dyskusji. Taki zestaw założeń musi być stosunkowo prosty, a nawet banalny. $\mathrm{O}$ ile twierdzenia te są wyrafinowane, subtelne i uczone, to prawdopodobnie nie będą podzielane przez zbyt wielu i dlatego nie stworzą światowej społeczności uczonych (...)

Po drugie, sądzę, że te wspólne założenia ujawniają się - co nie oznacza, że zostają wyraźnie sformułowane - w tym, kogo uważamy za myślicieli, którzy nas ukształtowali (Wallerstein, 2004, s. 265).

Autor Analizy systemów-światów sam rekonstruuje kulturę socjologii w postaci trzech przekonań, które przypisuje trzem różnym klasykom socjologii. Ja chciałbym skorzystać z Wallersteinowskiego narzędzia określania kultury danej dziedziny w odniesieniu do filozofii. Nie będę jednakże powtarzał jego metody działania, to znaczy nie pokuszę się o rekonstrukcję podzielanych przez filozofów założeń w postaci kilku twierdzeń. Zamiast tego chcę potraktować kilka wybranych wypowiedzi metafilozoficznych właśnie jako próby uchwycenia, w sposób bardziej złożony, kultury filozofii. Tym samym interpretuję wypowiedzi metafilozoficzne nie jako po prostu filozofowanie o filozofii (czym one niewątpliwie są!), ale jako twórczy wysiłek zmierzający do uchwycenia, jak mówi Wallerstein, „podzielanych założeń i praktyk, podzielanych wprawdzie nie przez wszystkich członków społeczności i nie zawsze, lecz przez większość z nich przez większość czasu”. 
Autorzy, których prace poddam takiej reinterpretacji, to Leszek Nowak i Józef Niżnik ${ }^{3}$. Dobór ten, choć może zdawać się przypadkowy, jest korzystny z uwagi na wysiłek uchwycenia szerokiego spectrum filozoficznych dociekań.

Kiedy już uda się dokonać rekonceptualizacji-przejścia od metafilozofii do kultury filozofii - będzie można tej świeżo wyłonionej kulturze profesjonalnej postawić kolejne pytanie: jaki typ praktyk poznawczych projektuje, dopuszcza, stosuje i rozpoznaje dana kultura? (model typów poznania). Rezultaty tych dociekań moglibyśmy następnie odnieść do szerszej dynamiki kultury, to znaczy wyjść poza jedynie kulturę filozofii i następnie poszukać w szerszym zakresie i bardziej bezpośrednio odpowiedzi na pytanie o kulturowe funkcje filozofowania.

\section{Przeciw zdrowemu rozsądkowi - Leszek Nowak}

Pośród zalet metafilozoficznej koncepcji Leszka Nowaka widzę między innymi takie dwie: Nowak zaczyna od przyznania, że filozofia jest nieredukowalnie pluralistyczna i z faktem tym nic począć się nie da (Nowak, 1998, s. 7, 65, 88$94^{4}$ ). Toteż rozsądny filozof, miast się z tym zmagać, usiłując wielość na różne sposoby zredukować, powinien ją zaakceptować, uznać niezbywalny pluralizm rozwijanych obok siebie filozofii. Filozofii, które odmiennie stawiają problemy, posługują się odmiennymi pojęciami oraz inaczej określają kryteria filozoficznego sukcesu. Drugą zaletą jest budowanie metafilozofii niejako przy okazji, Nowak nie koncentruje się bowiem na wywodzie metafilozoficznym dla niego samego. Rozbudowane uwagi metafilozoficzne stanowią dla Nowaka zaplecze, wyjaśnienie i kontekstualizację jego wywodu filozoficznego. Nie

\footnotetext{
${ }^{3}$ W książce Kulturowe funkcje filozofii poza Niżnikiem i Nowakiem analizuję jeszcze teksty Marka Siemka (1982) i Leszka Kołakowskiego (2000).

${ }^{4}$ Symptomatyczny jest sam początek książki, Leszek Nowak zaczyna bowiem tak: „Filozofia jest dziwną dziedziną. W każdej dyscyplinie ludzie mają teoriom konkurentów rozmaite rzeczy za złe, ale w każdej dobrze wiadomo, kto jest wielki uczonym, kto poważnym specjalistą, kto takim sobie, a kto jeszcze gorzej. W każdej dziedzinie znana jest i uznana - i to jeszcze za życia zainteresowanych - hierarchia osiągnięć i autorytetów. W żadnej innej - poza filozofią - dyscyplinie nie mogłoby się zdarzyć, by czołowi reprezentanci konkurujących szkół a więc najwybitniejsi z żyjących mieli się w autentycznej, wzajemnej i nieskrywanej pogardzie, za nic - dosłownie! - mając osiągnięcia wszystkich innych konkurentów" (Nowak, 1998, s. 7). I komentarz na marginesie: obraz nauki kreowany przez filozofia znów nie do końca odpowiada faktom. Można przywołać na przykład historię badań nad antropogenezą, by zakwestionować tutaj unikalność filozofii: hipoteza afrykańskiego pochodzenia homo sapiens długo torowała sobie drogę w umysłach naukowców koncentrujących się raczej na Europie, ewentualnie Azji, i bez stosownej weryfikacji naśmiewających się z pierwszych świadectw. Analogiczne trudności napotkała idea, by zastosować również techniki datowania pojawienia się człowieka oparte na biochemii, a nie jedynie oparte na materiale kopalnym (por. Morgan, 2010).
} 
mamy tu więc do czynienia z teorią konstruowaną dla teorii czy grami pojęciowymi toczonymi jedynie po to, by grać dalej. Zamiast tego jego metafilozofia ma działać w określonym kontekście.

Pierwsza $\mathrm{z}$ tych zalet wiąże się z celem niniejszych rozważań. Jeśli bowiem Nowak usiłuje uchwycić jakoś zróżnicowaną całość filozofowania, to dla nas oznacza to względnie pełne określenie kultury filozofii. Nieco jak u Kołakowskiego. Z tym, że gdy autor Kultury i fetyszy (Kołakowski, 2000) kreśli panoramę z lotu ptaka (tu transcendentaliści, tu scjentyści, a tu tradycjonaliści - por. Kołakowski, 2000, s. 15-44), to Nowak stara się to zrobić niejako od środka. W sposób bardzo zbliżony do Wallersteina w jego przywoływanym wcześniej tekście, Nowak podejmuje wysiłek, by ująć rozmaite, niekiedy niepowiązane ścieżki filozoficzne $\mathrm{w}$ kilka prostych zasad, rozstrzygnięć i rozróżnień. Ponieważ jego wywód jest przy tym wzorcowo przejrzysty, możemy od razu wyłuskiwać z niego cechy kultury filozoficznej.

Cecha pierwsza już została wskazana: „niezbywalny pluralizm teoretyczny” filozofii (Nowak, 1998, s. 65). W przywołanych w przypisie słowach wstępnych Nowak nawet przedstawia pewne postawy, rozpowszechnione sposoby radzenia sobie z owym pluralizmem. Przywołuje je zresztą po to, by przeciwstawić im własny wywód metafilozoficzny, który to zróżnicowanie stara się ująć w całość.

Drugą cechę kultury filozoficznej autor Bytu i myśli charakteryzuje tak:

Najbardziej bodaj charakterystyczną cechą myśli filozoficznej jest jej dziwaczność (Nowak, 1998, s. 66).

Dziwaczność ta bierze się stąd, że filozofia przeciwstawia się rozstrzygnięciom zdroworozsądkowym. Jest to ważny moment, dlatego należy przyjrzeć mu się trochę bliżej. Dziwaczność filozofii wskazuje na dwie rzeczy jednocześnie: jaki jest wspólny obszar dla filozofii i zdrowego rozsądku oraz, w konsekwencji, gdzie się one rozmijają. Jedno i drugie jest dla nas ważne. Posłużmy się ponownie cytatem:

Na potoczne oczywistości wytworzone w toku ewolucji naszego gatunku i historii ludzkiej kultury składają się intuicje rozmaitego rzędu, bardziej i mniej ukryte. Te dotyczące materii, którymi zajmuje się filozofia, są intuicjami ostatecznymi, na których wspierają się wszystkie inne. Są to zarazem intuicje najbardziej ukryte — a więc najbardziej naturalne; dlatego są też zwykle najbardziej niejasne - bo rzadko poddawane analizie (Nowak, 1998, s. 66).

Filozofii i zdrowemu rozsądkowi wspólne są intuicje, przeświadczenia najbardziej ukryte i ostateczne, rzec by można: najbardziej fundamentalne. Dlatego właśnie, jak widać, związek pomiędzy filozofią a dynamiką kultury może być bardzo istotny. Filozofia staje się tutaj ważnym mechanizmem do wykrywania podstawowych parametrów myślenia o świecie, a może kultury po prostu, a co za tym idzie - również różnicowania. Jeśli bowiem dysponuje narzędziami do 
zmiany tych parametrów w laboratoriach filozoficznych, to w konsekwencji być może jest w stanie zmieniać również samą kulturę. Krótko mówiąc, dziwaczność filozofii czasami narzuca się otaczającemu ją światu. Potwierdzenie tego w pewnej mierze uzyskujemy w dalszych częściach wywodu Nowaka (Nowak 1998, s. 74-75).

Autor Bytu i myśli oferuje nawet bardzo jasno skonstruowane narzędzie do mierzenia dziwaczności skontrastowanej z głębokimi intuicjami zdrowego rozsądku. Składa się ono z listy takich intuicji tworzących łącznie naturalny pogląd na świat. Przywołajmy odnośny fragment w całości, ponieważ jest on istotny dla określenia kultury filozofii:

Intuicja, o której wspomniano wyżej - „jest świat” - to intuicja istnienia świata. „Istnieje jeden tylko świat” (intuicja jedyności świata); „wszystko, co istnieje w świecie jest jakieś, nie istnieje zatem nicość" (intuicja pozytywności istnienia); „co jest jakieś, jest wskutek tego inne”(intuicja związków między pozytywnymi stronami istnienia); „budulcem świata są rzeczy, cała reszta to ich mniej lub bardziej pośrednie charakterystyki” (intuicja ostatecznej podstawy); „rzeczy zachowują się w potoku zmian” (intuicja stabilności); ,ja jestem w świecie” (intuicja autoistnienia); „moja myśl o rzeczy i sama rzecz to obiekty całkowicie odmiennej natury pierwszy jest we mnie, drugi na zewnątrz mnie" (intuicja subiektywności świadomości); „najpewniejszą wiedzę o świecie można uzyskać przez zmysły” (intuicja empiryzmu); „obserwacja zmysłowa rzeczy nie zmienia tej rzeczy" (intuicja akauzalności obserwacji) - oto przykładowe intuicje składające się na naturalny pogląd na świat. Naturalny, a więc taki, w który wierzy się bezwarunkowo i bezrefleksyjnie (Nowak 1998: 66).

Jeśli przyłożymy tę listę dziesięciu intuicji do dowolnej konstrukcji filozoficznej i wszystkie będą pasowały, to okaże się, że dana filozofia zgadza się ze zdrowym rozsądkiem (czy zgadza się w całej swej rozciągłości to inna kwestia). Jeśli zaś w którymś miejscu wywód filozoficzny naruszy daną intuicję, to wywoła on efekt dziwaczności (niedowierzania, sprzeciwu, etc.). I tu dochodzimy do trzeciej cechy kultury filozofii, jej podziału na filozofie spolegliwe i radykalne (Nowak, 1998, s. 67-68, 96). Filozofie spolegliwe spełniają pierwszy z powyższych warunków - są zgodne z listą dziesięciu intuicji i zajmują się po prostu ich eksplikacją, rozwijaniem, precyzowaniem etc. Z kolei filozofie radykalne naruszają przynajmniej jedną z tych intuicji:

\footnotetext{
${ }^{5}$ Wydaje mi się, że ten fragment jaśniej brzmiałby następująco: ,jeśli coś jest jakieś, to coś innego jest wskutek tego inne”.
} 
Toteż zadanie filozofii nie na tym polega, by cyzelować rzekome prawdy przez ludzkość zadane, lecz na tym, by owe intuicje naturalne jedna po drugiej kwestionować i wypróbowywać możliwość alternatywnych metafizyk. Wedle orientacji radykalnych - filozofia nie jest służebnicą, lecz sędzią zdrowego rozsądku (Nowak, 1998, s. 67).

Podział na filozofie spolegliwe i radykalne wraz z listą dziesięciu naturalnych intuicji metafizycznych pozwala skonstruować nam matrycę do opisu kultury filozoficznej. Nie dostajemy więc kilku przekonań, które z grubsza musimy przypisać wszystkim filozofom, zamiast tego wyjściowa matryca pozwala, jak w metodologii strukturalistycznej, skonstruować przestrzeń rozproszenia kultury filozoficznej.

No dobrze, tak to wygląda, gdy trzymamy się ściśle wywodu Nowaka. Pozwolę jednak sobie w tym miejscu na pewne uwagi krytyczne. Sporządzenie listy dziesięciu naturalnych intuicji metafizycznych może zrazu wydać się jak najsłuszniejsze, wszak filozofki i filozofowie znają dobrze doświadczenie dziwaczności filozofii i jej odstawania od zdrowego rozsądku. Można jednak zapytać: według jakiej metodologii lista ta została skonstruowana? Więcej: jakie argumenty przemawiają na rzecz trwałości i stabilności tych intuicji w zdrowym rozsądku?

A oto dwa, może dość zabawne kontrprzykłady. Pierwszy dotyczący intuicji subiektywności świadomości („moja myśl o rzeczy i sama rzecz to obiekty całkowicie odmiennej natury - pierwszy jest we mnie, drugi na zewnątrz mnie”). Być może w większości przypadków rozróżnienie rzeczy i myśli o rzeczy czynimy automatycznie. Co jednakże począć z urokami? Jak wtedy, gdy mówimy „wypluj to słowo” albo boimy się głośno wypowiadać negatywnych określeń na temat swój czy bliskich (np. „gdyby mój ojciec był w tej chwili umierający...”). Oczywiście dobrze wiemy, że słowa to słowa, a realny świat to realny świat, ale mechanizm uroku działa.

Drugi kontrprzykład dotyczy kwestii, która szczególnie Nowaka interesuje, to jest pozytywności i negatywności. Zwłaszcza myślę tu o intuicji związków między pozytywnymi stronami istnienia. Wielu rodziców niemowlaków napotyka problem ujmowany jako „brak kupki”. Zdarza się, że całkowicie zdrowe niemowlę przechodzi przez etap, kiedy nagle z dnia na dzień przestaje się wypróżniać często, a zamiast tego robi to raz na kilka dni, niekiedy jedynie stymulowane specjalnymi czopkami. Zwykle wprowadzenie pokarmów stałych (w tym przetartych śliwek) problem rozwiązuje, ale wobec określonego kalendarza karmienia zainteresowani muszą niekiedy na to rozwiązanie czekać tygodniami. I podkreślam, problemem nie jest wtedy sama kupka, ale jej brak ${ }^{6}$.

\footnotetext{
${ }^{6}$ Łatwo sprawdzić powszechność takiego formułowania problemu korzystając z wyszukiwarki internetowej. Przykładowe rezultaty znajdują się na stronach: http://parenting.pl/portal/brak-kupyu-noworodka, http://f.kafeteria.pl/temat.php?id_p=4358525, http://www.edziecko.pl/pierwszy_rok/ 1,79401,3866857.html; dostęp 20.15.2013. Łatwo oczywiście znaleźć przeformułowanie problemu
} 
Rodzice korelują inne zjawiska (pozytywne) z tym przypadkiem braku, zjawiskiem negatywnym.

Można oczywiście argumentować, że mamy tu do czynienia z aberracjami $\mathrm{w}$ łonie zdrowego rozsądku, albo z takim naruszaniem naturalnych intuicji, które nawet dla samych naruszających są niezauważalne. Jednakże jeśli je arbitralnie wykreślimy, rekonstrukcja naturalnych intuicji metafizycznych przestanie być ujęciem opisowym, a zamieni się w postulatywne. W rezultacie również podział na filozofie spolegliwe i radykalne staje się postulatywny czy po prostu roboczy, bo wiarygodny, ale jedynie w pewnych granicach. I granic tych z góry nie znamy ${ }^{7}$.

Powtórzę - są to jedynie uwagi poboczne, ponieważ nie zmieniają one oczywiście głównego zadania rekonstrukcji kultury filozoficznej oraz przekładu poznawczych mechanizmów filozofowania na kategorie teorii kultury. Jednakże te uwagi krytyczne wiążą się z moimi dalszymi tezami, w których będę utrzymywał, że filozoficzna panorama kultury jest znacznie bardziej kolorowa i zróżnicowana niż sugerowałaby lista Nowaka. Tym samym zaś związków „profesjonalnej” filozofii jako systematycznego namysłu z naturalnym, zdroworozsądkowym filozofowaniem jest znacznie więcej i są one bardziej różnorodne.

Wróćmy jednak do głównej osi wywodu. Przedstawiony powyżej podział na filozofie spolegliwe i radykalne służy Nowakowi, przy pewnych zastrzeżeniach, do potraktowania tylko tego drugiego typu jako filozofii właściwej. Piszę o zastrzeżeniach, ponieważ Nowak nie odrzuca $\mathrm{w}$ jakimś zacietrzewieniu filozofii spolegliwych jako filozofii fałszywych. Kreśli podział i wychodzi od niego w dalszych rozważaniach (argumentując między innymi, że powszechność naturalnych intuicji wcale nie świadczy o ich prawdziwości, a zatem filozof jest zobowiązany do testowania alternatyw). Wiemy już zatem, że filozofia ma różnić się od zdrowego rozsądku (jako filozofia radykalna) i ma odróżniać się również od nauki (Nowak, 1998, s. 68) ${ }^{8}$, ale posiada pewne zbieżności ze sztuką, obie bowiem odkrywają przed nami nowe światy (Nowak, 1998, s. 69). Charakterystyczną cechą tych eksploracji jest całościowość, co możemy zapisać jako kolejną charakterystyczną cechę kultury filozoficznej:

Jej odrębność polega raczej na tym, iż stara się uchwycić Całość przezierającą poprzez światy (resp. uwidaczniającą się w różnych jego aspektach). Różne systemy filozoficzne inaczej ją uchwytują, w każdym z nich jednak idzie o Całość.

na „zaparcia u niemowlaka” - np. http://dziecko-info.rodzice.pl/showthread.php/175512-Zaparcieu-niemowlaka, dostęp 20.05.2013.

${ }^{7}$ Można tu również argumentować w duchu Slavoja Žižka, że całość nigdy nie jest spójną, organiczną całością, a zawsze wewnętrznie popękaną, pełną konfliktów, dialektyczną całością Hegla (por. Żižek, 2012, s. 378); dogłębną analizę zagadnienia nie-całości u Žižka i innych filozofów słoweńskich można znaleźć w książce Kuby Mikurdy Nie-całość. Žižek, Dolar, Zupančič (2015).

${ }^{8}$ Rzecz jasna nie znaczy to, że ma być „antynaukowa”. 
Każdy system zmierza do podważenia zastanego zestawu intuicji dotyczących Całości, rewiduje go - zastępuje nowym. Systemy filozoficzne różnią się od teorii naukowych czy dzieł sztuki tym, iż są obrazami Całości, nie zaś obrazami fragmentów czegoś, o czym się nic nie wie (Nowak, 1998, s. 69).

Poniżej Nowak podsumowuje tę część wywodów metafilozoficznych:

Pierwszą konstytutywną cechą filozofii (w gatunkowym tego słowa znaczeniu) jest więc nastawienie na nieustanną rewizję intuicji metafizycznych właściwych zwykłym, nie filozofującym ludziom. Drugą jest „marzenie o racjonalnym ujęciu Całości” (Nowak 1998, s. 69).

I dalej konkluduje jeszcze bardziej syntetycznie:

Filozofia jest najpierw zburzeniem metafizyki naturalnej, a potem odbudową całościowego obrazu istnienia. Filozofia (w sensie gatunkowym!) polega więc na rewolucyjnej rekonstrukcji Całości (Nowak, 1998, s. 69).

Gatunkowe rozumienie filozofii oznacza robotę analogiczną do tej, którą wykonuje poznański filozof - rozpoznajemy filozofię poprzez przypisanie jej pewnych cech gatunkowych. Nowak praktycznie czyni to samo, co czynimy tutaj określając kulturę filozofowania, choć nazywa to inaczej. Alternatywą wobec rozumienia gatunkowego - czy też jego przeciwieństwem - jest podejście historyczno-opisowe (też pewnie w jakiejś mierze niewolne od aspektu gatunkowego), posługujące się historycznym materiałem już uznanym za część tradycji filozoficznej (por. Nowak, 1998, s. 68). Należy tu jednak dodać ważne zastrzeżenie: możemy operować na gatunkowo pojmowanej filozofii tylko pod warunkiem metafilozoficznej relatywizacji, to znaczy wyłącznie jeśli ujawnimy własne kryteria przynależności do kultury filozoficznej. Inaczej, w sytuacji niejawnych przesądzeń, pojawia się groźba zamiany rozumienia gatunkowego w perswazyjne (Nowak, 1998, s. 68).

Widzimy więc, że lista cech opisujących kulturę filozoficzną jest stosunkowo prosta i krótka: 1. Filozofia występuje przeciw zdrowemu rozsądkowi; 2. Filozofia stara się uchwycić całość. Do tych dwóch cech można, uzupełniająco, dorzucić kolejne: 3. Filozofia odróżnia się od nauki właśnie tymi cechami, ale poza tym może starać się być jak nauka (ścisła, rzetelna, sceptyczna, gotowa na odrzucenie twierdzeń bezpodstawnych); filozofia odróżnia się od sztuki między innymi koncentracją na całości, a nie na szczególe, ale dzieli z nią umiejętność odkrywania nowych światów (patrz cecha 1). Pierwszą własność możemy w kolejnym kroku rozwinąć, dodając przywołaną wcześniej listę naturalnych intuicji metafizycznych, która, jak wcześniej wskazałem, pozwoliłaby nakreślić mapę rozproszenia kultury filozoficznej. Mapa taka wychodziłaby od wskazania, które z tych intuicji zostały obalone, a następnie wskazania, co je zastąpiło.

Jak widzimy, model Nowaka jest prosty, elegancki i kilkupłaszczyznowy możemy bowiem opisać go bardzo skrótowo, a możemy zdecydować się na wprowadzenie do gry większej liczby szczegółów. Warto go jeszcze dodatkowo 
rozszerzyć o wskazane przez tego filozofa dwa stany emocjonalne czy też postawy poznawcze charakteryzujące filozofów: zdziwienie i znudzenie.

Filozofia nie powstaje ze zdziwienia, ale ze znudzenia. Znudzenia banalnością naszych codziennych intuicji naturalnych. Prowadzi natomiast do zadziwienia. Im bardziej zdumiewa, tym jest lepsza - jako filozofia, a więc jako alternatywny w stosunku do naturalnego obraz Całości. Jej ostateczną funkcją kulturową jest bowiem rugowanie więzów podmiotowych, wykorzenianie ograniczeń narzucanych nam przez naszą ludzką kondycję. Jeśli więc filozof (nie mylić z „pracownikiem naukowym z zakresu filozofii”) instynktownie usiłuje być oryginalnym, to nie $\mathrm{z}$ pustoty, lecz $\mathrm{z}$ obowiązku społecznego. Jak ciężkiego i niewdzięcznego, nie pojmie, kto sam choć raz w życiu nie naraził się innym ludziom (Nowak, 1998, s. 81).

Cytat ten przywołuję w tak szerokiej formie, aby pokazać, że faktycznie dodanie znudzenia i zdziwienia opisuje kulturę filozoficzną, wszak autor Bytu i myśli wyraźnie mówi tu o działaniach instynktowych (internalizacja norm tej kultury), o stosunku do innych ludzi oraz o obowiązku społecznym (ponowna internalizacja hierarchii wartości i powinności).

Zrekonstruowanie kultury filozoficznej nakreślonej przez Nowaka w pierwszym tomie Bytu i myśli pozwala wreszcie wrócić do pytań o opisane tu mechanizmy poznawcze.

Przejrzysty wywód Nowaka ułatwia nam pracę, choć jednocześnie nie musi to oznaczać, że wciśnięcie jego rozróżnień w model czterech typów poznania będzie łatwe. Zacznijmy od filozofii spolegliwej. Tu sprawa nie powinna być kłopotliwa - jej cechą definicyjną jest rekonstruowanie gotowych, naturalnych intuicji metafizycznych w profesjonalnym żargonie filozofii ${ }^{9}$. Interpretuję to jako wyraz poznania poprzez odtwarzanie i odkrywanie. Pierwszym krokiem jest z konieczności odtwarzanie, ponieważ stanowi ono warunek wyjściowy zdrowy rozsądek musi być rozpoznany, aby następnie wyrazić jego rozstrzygnięcia w inny sposób. Następnym krokiem może być odkrywanie, co widać w przywołanej w przypisie wypowiedzi poznańskiego filozofa, ponieważ może okazać się, że zdrowy rozsądek nie uchwycił wszystkich niuansów czy konsekwencji własnych intuicji metafizycznych ${ }^{10}$. Taki jest zakres tych form filozofowania. Tutaj filozofia spolegliwa schodzi ze sceny.

Ciekawszym przypadkiem są filozofie radykalne. Skoro ich cecha definicyjna to łamanie naturalnych intuicji metafizycznych czy - jak chce Nowak w innym

\footnotetext{
${ }^{9}$ Leszek Nowak powiada: „wszystko, co filozof ma na tym terenie do zrobienia, to eksplikacja owych intuicji na sposób dyskursywny, przebadanie ich stosunków wzajemnych, w szczególności tego, czy są one spójne itd.” (Nowak, 1998, s. 67).

${ }^{10}$ Por. np. następujący komentarz dodany przez autora w przypisie: „To, że koncepcja jest spolegliwa, znaczy, iż zasadnicze jej tezy (,aksjomaty") są nastawione na rekonstrukcję zdrowego rozsądku metafizycznego, nie pociąga to samo przez się natomiast, iż wszystkie jej twierdzenia mieszczą się w tych ramach” (Nowak, 1998, s. 96, przypis 1).
} 
miejscu - odkrywanie nowych światów (Nowak, s. 1998, s. 69), to należy przypuszczać, że właśnie uzyskujemy projekt działalności redefiniującej lub projektującej. Tylko której z nich? Może obu naraz? Kluczem do odpowiedzi jest aspekt, na który zwróciłem uwagę wcześniej w komentarzu na marginesie. Autor Bytu i myśli wyraźnie podkreśla, że obszar zmagania określa zawartość zdrowego rozsądku. To on jest i pozostaje punktem odniesienia. Toteż manipulacje przy którejś z dziesięciu tez naturalnych intuicji metafizycznych koniec końców odnoszą się na powrót do zdrowego rozsądku. Filozofia radykalna może zatem przedefiniować nasz zdroworozsądkowy pogląd na świat, może wzbudzić zdziwienie właśnie w tym rozejściu się spojrzenia codziennego i niecodziennej perspektywy filozoficznej. I na tym koniec.

Być może kategoria zdrowego rozsądku w tej formie została - jak wskazywałem wcześniej - przez Nowaka zbyt pośpiesznie i bezrefleksyjnie przyjęta. Jak argumentowałem powyżej, nie wydaje mi się on równie jednorodny. Ponadto, jak staram się wykazać w dalszej części książki (Abriszewski, 2013, s. 151-169) powołując się na Petera Bergera i Thomasa Luckmanna (1983), nasza codzienność daleka jest od jednorodności, oczywistości i ustabilizowania. Zakładanie więc, że zdrowy rozsądek może być tak po prostu względnie sztywny i ustabilizowany, okazuje się zbyt pochopne.

Niemniej, mimo całej, olbrzymiej sympatii Nowaka dla sił stwórczych filozofii radykalnych nie pozostawia on miejsca dla mechanizmu projektowania nowych obszarów doświadczenia kulturowego. Oczywiście, wykorzystując model czterech typów poznania, możemy powiedzieć, że w tym miejscu, gdzie poznański filozof podsuwa zdrowy rozsądek, można poszerzyć jego wywód. Wskazuję na tę możliwość, ponieważ widzimy, że proponowana metafilozofia (kultura filozofii) otwiera nową ścieżkę poznawczą. Tutaj nie tylko filozofii przypisuje się szczególną pozycję w kulturze, otrzymuje ona również pewne szczególne kompetencje. Innymi słowy, niezwykłe moce poznawcze filozofii są tu nie tylko deklaratywne, ale faktyczne, przynajmniej w zakresie redefiniowania naszego doświadczenia potocznego. Filozofia radykalna może zmienić nasze postrzeganie całości. Nie ma jednak słowa na temat faktycznego zmieniania tej całości tak, by pojawiło się coś zupełnie nowego.

\section{Funkcja i status - Józef Niżnik}

O ile Leszek Nowak wszedł $\mathrm{w}$ rozważania metafilozoficzne przy okazji swojej pracy filozoficznej, o tyle Józef Niżnik również nie zaczyna wprost i od razu od lokowania się na metapoziomie filozofowania, a zamiast tego wychodzi od kulturowej sytuacji filozofii. Dla Nowaka w pewnym sensie relacja do zdrowego rozsądku (naturalnych intuicji metafizycznych) była zwornikiem całego wywodu metafilozoficznego. Niżnik dla odmiany wskazuje na relacje między myśleniem potocznym, zdroworozsądkowym, a filozofowaniem i stara się je 
wyjaśnić. Nowak wykazuje w metapoziomowym rozumowaniu, że tezy filozoficzne nabierają mocy (wyjściowo, między innymi) w zależności od tego, jak ustawiają się wobec zdroworozsądkowych intuicji metafizycznych. Niżnik analizując złożoną relację między statusem filozofii a jej (prymarną) funkcją, stawia tezę, że ważność tez filozoficznych zależy od postrzegania samej filozofii, od przyjętej - milcząco lub jawnie - metafilozofii. Zatem wywody Nowaka są tutaj znakomitą egzemplifikacją dla tezy autora Arbitralności filozofii.

Widać pewne zbieżności między Nowakiem i Niżnikiem, jednakże jasne jest również pewne przesunięcie. U Nowaka pojawiły się jedynie pojedyncze uwagi dotyczące relacji między filozofią i jej otoczeniem kulturowym oraz tego, jaki pożytek może mieć ta druga z tej pierwszej. Bazując na jego modelu, łatwiej byłoby uchwycić rolę filozofii w kulturze koncentrując się na pierwszoplanowej jej relacji ze zdrowym rozsąadkiem. Niżnik znacznie dalej podąża tropem ulokowania filozofii w jej otoczeniu kulturowym.

Jak już powiedziałem, rozpoczyna on od rozpoznania sytuacji filozofii. Wskazuje na często przywoływany stan kryzysowy, przyjmujący formę kryzysu tożsamości tej dziedziny. Jednocześnie zwraca uwagę, że zbiega się on $z$ rozprzestrzenianiem się antyfundamentalizmu epistemologicznego (Niżnik, 1999, s. 7). Jaki jest tutaj związek? Filozofia (epistemologicznie fundamentalistyczna) przyjęła na siebie zadanie stworzenia absolutnych i niepodważalnych podstaw wiedzy. Lokowała się tym samym „poniżej” nauki oraz „gdzie indziej” niż sztuka. Tym samym zadanie to nie tylko wyznaczało cel działania, ale dodatkowo nadawało tożsamość dziedzinie poprzez odróżnienie się od dziedzin pokrewnych. Kariera antyfundamentalizmu epistemologicznego wiązała się $\mathrm{z}$ upowszechnianiem się przekonania, że filozofia jest bezsilna wobec jakiegoś wyobrażonego fundamentu wiedzy, że nie ma ona doń żadnego uprzywilejowanego dostępu. W rezultacie okazało się, że król jest nagi i w dodatku samotny, że roszczenia filozofii więcej mówiły o jej arogancji niż faktycznych osiągnięciach czy możliwościach. Jeśli zaś runął tak pojmowany rdzeń, to utracona została przez nią tożsamość, nadto zaś filozofia odkryła, że pozostaje odizolowana „od wielu innych nurtów życia intelektualnego, włączając $\mathrm{w}$ to naukę" (Niżnik, 1999, s. 8).

Autor Arbitralności filozofii wyciąga z tego taki oto wniosek, że status filozofii jest kwestią zmienną i niestabilną. Nie można zatem rozciągać na całą historię filozofii jakiejś jednej formuły określania tegoż statusu. Pytanie o jedność filozofii musi z kolei być stawiane w obliczu zmienności i wielości statusów. Toteż nie tyle należy ono do wewnętrznej problematyki filozoficznej, ile do patrzącej na nią z zewnątrz socjologii wiedzy. Tak ujmuje to Niżnik:

Mówiąc 0 „współczesnym” statusie filozofii sugeruje się, że status tej dyscypliny bywał inny w przeszłości. Zmierzając więc do określenia współczesnego statusu filozofii nie można uniknąć pytania o to, na czym zasadza się jedność filozofii w ytuacji historycznych zmian jej statusu czy też jej „paradygmatu”? Innymi 
słowy, musimy spróbować wyjaśnić, jak to się dzieje, że zmieniając swój status filozofia jest stale identyfikowana jako filozofia. Pytając o „status” dążymy do rekonstrukcji tych cech, dążeń i ambicji filozofii, które są odpowiedzialne za jej subiektywnie, ale dostatecznie szeroko postrzegane miejsce wśród innych produktów intelektualnej aktywności człowieka (Niżnik, 1999, s. 30).

I dalej:

„Pytanie o status - tak jak je rozumiem - należy więc nie tyle do „wewnętrznej” charakterystyki filozofii, co do jej „socjologii”. Wspomniane cechy, dążenia i ambicje filozofii muszą bowiem nieuchronnie artykułować się w języku danej epoki uwzględniając strukturę jej symbolicznego uniwersum. Dlatego pytanie o status filozofii można lokować w socjologii wiedzy. Równocześnie, wyznaczana przez nie problematyka jest filozoficznym namysłem nad filozofią - należy więc bez wątpienia do metafilozofii. W ten sposób dochodzimy do wniosku, że obszar, który nas zajmuje, jest taką częścią metafilozofii, która mieści się w zakresie problemowym socjologii wiedzy (Niżnik, 1999, s. 31).

Choć kwestia statusu filozofii nie jest wcale centralna w tym miejscu, to pozwala ona wykazać, że problematyka metafilozoficzna jest zarazem problematyką z zakresu socjologii wiedzy. Te obszerne cytaty i nieco większa ilość poświęconego jej miejsca niż zdawałoby się to konieczne mają, częściowo po fakcie, a częściowo „w biegu”, uzasadnić, jeszcze inaczej niż zrobiłem to na początku, że redefiniowanie kwestii metafilozoficznych w kategoriach teorii kultury i socjologii wiedzy jest uzasadnione.

By postawić sprawę jeszcze inaczej: z pewnej perspektywy, możemy powiedzieć, że mówienie o filozofii za pomocą narzędzi teorii kultury i socjologii wiedzy jest odejściem od filozofii samej. I jest to perspektywa do pewnego stopnia uzasadniona. Jednakże Niżnik oferuje nam jeszcze inną, drugą perspektywę. Według niej mówienie o filozofii za pomocą teorii kultury i socjologii wiedzy oznacza uprawianie pewnej formy metafilozofii, tym samym pozostanie w obrębie filozofii mimo pozornego z niej wyjścia. Można zasadnie utrzymywać, że niniejszy wywód lokuje się zarazem w filozofii, w teorii kultury i w socjologii wiedzy oraz że nie sposób przypisać go do jednej tylko z tych dziedzin odcinając pozostałe.

Zauważmy tutaj jedynie na marginesie, że oznacza to, iż nie tylko reinterpretujemy, „oglądamy” filozofię poprzez inne narzędzia intelektualne. Na końcu bowiem, pozostając cały czas w obrębie filozofii, możemy zwrotnie coś na temat filozoficznej działalności postulować. Innymi słowy, perspektywa intymnego powiązania metafilozofii, socjologii wiedzy i teorii kultury powoduje, że uprawiamy nie tylko dyskurs opisowy czy analityczny. Powoduje przede wszystkim, że w trybie metafilozoficznym wcześniejsze analizy mogą prowadzić do postulatów normatywnych co do kształtu czy formy funkcjonowania samej filozofii. 
Pytając wprost: skoro nie status, to co? Odpowiedź Niżnika jest następująca: tożsamość filozofii niekoniecznie trzeba pojmować w kategoriach jakiegoś zakresu treści teorii czy określonych pytań uznawanych za wyjątkowo istotne czy szczególnie charakterystyczne dla filozofii. Wielości i zmienności statusów filozofii nieustannie towarzyszy jedność jej funkcji wobec kultury (Niżnik, 1999, s. 34). Funkcja ta jest pierwotna, nieusuwalna i niezmienna (Niżnik, 1999, s. 34):

Funkcją tą było zapewnienie spójności ludzkiego uniwersum symbolicznego. Tej funkcji filozofia nie jest w stanie z siebie zrzucić, ponieważ w realizacji tak rozumianego zadania okazuje się ona jedyną formą wysiłku intelektualnego dostatecznie w tym względzie skutecznego (Niżnik, 1999, s. 9).

W innym miejscu powtarza tę tezę z nieco zmienionym kontekstem:

Funkcja ta to zapewnienie spójności symbolicznego uniwersum człowieka i w ten sposób ufundowanie, a następnie gwarantowanie koniecznego sensu. Sensu rozumianego zarówno jako podstawowa kategoria naszego dyskursu, jak i jako oczekiwana przez nas właściwość naszego świata. Toteż filozofia narodziła się wraz z „wynalezieniem” sensu, rozumu, prawdy i dobra, będąc uswych początków źródłem symbolicznego wymiaru ludzkiego świata w ogóle (Niżnik, 1999, s. 35).

Wyakcentujmy raz jeszcze przesunięcie, które wprowadza Niżnik: nie określamy filozofii przez jakiś zakres problemowy bądź sposób działania, a poprzez relację wobec jej otoczenia. Otoczeniem tym jest „symboliczne uniwersum człowieka”. Relacja polega zaś na zapewnianiu mu spójności. Dla wyklarowania sytuacji możemy tutaj wprowadzić pewne rozróżnienie, które może okazać się pomocne: potraktujmy funkcję uspójniania ludzkiego uniwersum symbolicznego jako własność filozofowania, to jest pewnej działalności polegającej na majsterkowaniu pojęciami. Z kolei określenie „filozofia” możemy zarezerwować wtedy dla: w sensie wąskim (1) jedynie wytworów operacji filozofowania, w tym jeszcze węziej (1A), nazywając tak jedynie filozofię rozpoznawaną przez tradycję akademicką; bądź w sensie szerokim (2) dla wszystkiego tego co jakoś z filozoficznością się kojarzy: operacji filozofowania, komentowania i reinterpretowania filozofów, ale również dla wytworów wszystkich tych działań.

Rozróżnienia te oczywiście nie są precyzyjne, chcę jednak zwrócić uwagę na różne użycia słów „filozofia” i „filozofować”. Niekiedy stosujemy je wyjątkowo wąsko (1A), niekiedy bardzo szeroko (2), niekiedy zaś po prostu wąsko (1), teoriocentrycznie, a jednocześnie pragnąc wyjść poza filozoficzny akademizm (kiedy powiemy na przykład o antropologii Witolda Gombrowicza). Z tego zbioru różnych użyć wyodrębniam czasownik „filozofować”, ponieważ interesuje mnie kulturowa funkcja działań, które możemy tym mianem określić. Oczywiście ciekawym problemem jest kulturowa rola spuścizny filozoficznej (1A), tak jak obecność idei filozoficznych $\mathrm{w}$ pismach filozofów i zarazem 
pismach pozafilozoficznych (1). Podobnie jak fascynujące może okazać się tropienie kulturowej roli filozofii $w$ jak najszerszym znaczeniu (2). Rozróżnienia te jednakże mają wskazać na perspektywę, którą przyjmuję - interesuje mnie tu jedynie, co się dzieje, kiedy filozofujemy. W dodatku interesuje mnie nie wymiar psychologiczny albo ideowy filozofowania, ale kulturowy. Mówiąc inaczej, ciekawi mnie, co zmienia się w porządku kultury, gdy filozofujemy.

Zawracam uwagę na te rozróżnienia, ponieważ teza Niżnika mówi o procesie o uspójnianiu. Chcę zatem, wierny jego stanowisku, pozostać przy tym procesualizmie.

Pojęcia ludzkiego uniwersum symbolicznego oraz jego uspójniania będą kluczowe dla dwóch kolejnych części książki (Abriszewski, 2013, s. 135-319). Zanim jednak wyjaśnię dlaczego, chciałbym powrócić do rekonstrukcji modelu Niżnika.

Mechanizm uspójniania ludzkiego uniwersum symbolicznego działa poprzez arbitralne akty filozofowania, w których wynajdywane są punkty orientacyjne (dyskursu, myślenia, naszej wyobraźni) pozwalające zrekonstruować świat symboliczny tak, że nabiera on zrozumiałych kształtów (Niżnik, 1999, s. 9, 35). Te zrozumiałe kształty przyjmują postać struktur sensu wyłaniających się z arbitralnych aktów filozofowania - parafrazując, narzucania na świat kategorii pojęciowych wynalezionych przez osobę filozofującą. Koniec końców pozwalają one sens nie tylko wytworzyć, ale jeszcze ustabilizować, tym samym stabilizując całość (czy też pewną całość) uniwersum symbolicznego.

Jeśli rozpoznanie Niżnika jest trafne, to oznacza ono ni mniej, ni więcej, że filozofowanie jest kulturową koniecznością, jeśli tylko przyjmiemy antropologiczne założenie o konieczności poczucia sensu. Taki kulturowy powszechnik jest jednakże sformułowany w sposób formalny, nie mówi to zaś zupełnie nic o jego zawartości. By powrócić do pojęć autora Arbitralności filozofii, fakt zachodzenia tej prymarnej funkcji nie wyznacza tego, jaki jest lokalnie (kulturowo, historycznie) status filozofii.

To prowadzi do obserwacji, jaką badacz ten czyni w dalszym ciągu swego wywodu: filozofia pokrywa się ze zdrowym rozsądkiem czy też myśleniem potocznym (Niżnik, 1999, s. 36). Gdyby wykorzystać powyżej wprowadzone przeze mnie rozróżnienia, to można powiedzieć, że filozofia będzie podzielała z myśleniem potocznym właśnie akty filozofowania. Chociaż potrzebne jest tu pewne zastrzeżenie:

Identyczności funkcji filozofii i myślenia potocznego towarzyszy dramatyczna odmienność form realizacji tej funkcji. Jesteśmy skłonni twierdzić, że formą tą było dla filozofii teoretyzowanie (Niżnik, 1999, s. 36). 
Choć oczywiście teoretyzowanie będziemy tu pojmować jako systematyczne i choćby względnie uporządkowane manipulowanie pojęciami w opozycji do zdroworozsądkowego operowania, które będzie mniej systematyczne, mniej uporządkowane, być może bardziej zorientowane na konteksty praktyczne i bez całego aparatu odniesień do korpusu literatury, to Niżnik wskaże nieco dalej jeszcze inną własność:

Sformułowania te (Diltheya i Horkheimera, które są wcześniej przywołane - K. A.) nie chwytają jednak najistotniejszej cechy tego sposobu, w jaki filozofia realizuje swoją funkcję. Cechą tą jest arbitralność filozofii. Filozofia, w odróżnieniu od myślenia potocznego, nadała sobie prawo tworzenia odrębnych dyskursów, które niemal bez ograniczeń mogą przeciwstawić się wszelkim załamaniom spójności ludzkiego świata (Niżnik, 1999, s. 36).

Zdaniem Niżnika, to właśnie jest główny wyróżnik filozofii oddzielający ją od myślenia potocznego - filozofowie są mniej lub bardziej świadomi (przynajmniej praktycznie), że „za pomocą arbitralnych decyzji semantycznych można kreować swój świat” (Niżnik, 1999, s. 36-37).

Widzimy zatem, że powraca tu pokrewieństwo z argumentacją Leszka Nowaka - także tutaj filozofia jest konkurentem czy głównym przeciwnikiem myślenia potocznego. Inne są jednakże przyczyny i mechanizmy tej konkurencji, chociaż prowadzą do podobnej konkluzji: u Nowaka należy filozofując wyłamywać się z dyktatu zdrowego rozsądku, u Niżnika zaś w toku filozofowania dojdzie do arbitralnych aktów wynajdywania punktów orientacyjnych. W obu przypadkach filozofia poznawczo wyruszy dalej niż wskazuje myślenie potoczne. Dalej, czyli poza horyzont potoczności. A to z kolei prowadzi nas znów do pytania o to, jakie typy poznania oferuje filozofia według Niżnika.

Taka podróż poza horyzont potoczności podpowiada, że w modelu Niżnika nie ma miejsca dla (filozofii jako) poznania $\mathrm{nr}$ 1, polegającego na odtwarzaniu. Może ono nawet wypełniać większą część operacji dokonywanych w Akademii, czy to w ramach wykładów, seminariów, konferencji, czy też w postaci pisania tekstów. Niezależnie jak szeroko albo wąsko się rozlewa, w modelu, który właśnie zrekonstruowaliśmy, nie tędy droga.

W jednym miejscu, mówiąc o arbitralności filozofii, Niżnik zauważa:

Filozofia, w odróżnieniu od myślenia potocznego, nadała sobie prawo tworzenia odrębnych dyskursów, które niemal bez ograniczeń mogą przeciwstawić się wszelkim załamaniom spójności ludzkiego świata (Niżnik, 1999, s. 36).

To jest właśnie kontekst dla przywoływanego w pracy Niżnika cytatu z Maxa Horkheimera, w którym o filozofii mówi się jako o wnoszącej rozum do świata (Niżnik, 1999, s. 36). Nieco dalej, autor Arbitralności filozofii sprawę jeszcze „dociska”: 
Filozofia, w odróżnieniu od myślenia potocznego, nadała sobie prawo tworzenia odrębnych dyskursów, które niemal bez ograniczeń mogą przeciwstawić się wszelkim załamaniom spójności ludzkiego świata (Niżnik, 1999, s. 36-37).

Ta arbitralność, moc tworzenia dyskursów, a tym samym (współ)kreowania świata, przynajmniej zaś uniwersum symbolicznego, uwydatnia się jeszcze bardziej w kolejnych odwołaniach do historii filozofii: do Fichtego mówiącego, że filozof „dysponuje absolutną wolnością nadawania kierunku swojemu duchowi” (Niżnik, 1999, s. 37) i do Nietzschego piętnującego mumifikację, czyli nadmierne przywiązanie do „już wynalezionych rozwiązań pojęciowych” (Niżnik, 1999, s. 38).

Widzimy wyraźne wydobycie aspektu stwórczego, konstruktywnego w filozofowaniu, przy jednoczesnym odniesieniu krytycznym do przypadków jego zagubienia. Wcześniej powtarza się na różne sposoby fakt „niemal nieograniczonego” potencjału stwórczego.

Ta ścieżka wywodów Niżnika nakazuje przypuszczać, że w omawianym modelu filozofowanie jest redefiniowaniem i projektowaniem (3. i 4. typ poznania). Możliwości reagowania na każde załamanie uniwersum symbolicznego sugerują, że nie chodzi wcale wyłącznie o odkrycie (typ poznania $\mathrm{nr}$ 2) i opisanie mechanizmów rozerwania, ale o jego przepracowanie, wytworzenie łaty z nowej materii myślowej. Oczywiście możemy przypuszczać, że w jakiejś mierze obejmie to również odkrywanie, ale jedynie jako uzupełniający mechanizm poznawczy.

Józef Niżnik reprezentuje więc radykalną metafilozofię, radykalnie optymistyczną wobec możliwości filozofowania i równie optymistyczną, jeśli chodzi o wagę funkcji, jaką filozofowanie pełni w kulturze. Gorzkim uzupełnieniem zaś niech będzie uwaga, że pociąga to za sobą pesymizm, jeśli chodzi o kulturowo-rynkową rolę filozofii jako dostarczycielki kompetencji dla określonego obszaru, jak wytwórczyni ról zawodowych. Nie istnieje zawód „profesjonalny sklejacz kultury”, nie sposób zamieścić nigdzie ogłoszenia „łatam na zamówienie symboliczne uniwersum, ceny konkurencyjne”. Załamania uniwersum symbolicznego nie podlegają logice rynku pracy. Choć zaistnienie tego rodzaju procesów gdzieś zostanie systemowo wymuszone, do jakichś ról zostaną dopisane (np. kapłana, nauczyciela, pisarza, terapeuty), to nie sposób ich wycenić, ustalić wartości, bo są zawsze „nie z tego świata”, czy, jak mówi, Nietzsche „niewczesne”11.

Wniosek ten każe zwrócić uwagę na pewną trudność z modelem Niżnika. Jego formalne ujęcie - wejściem do filozofii jest funkcja wobec kultury - powoduje, że nie sposób przyszpilić kultury filozofii. Nie ma bowiem zestawu przekonań,

\footnotetext{
${ }^{11}$ Cecha ta powoduje, że wobec współczesnej intensywnej komodyfikacji akademii, często zmyłkowo zwanej „modernizacją”, „rozwojem” itp., humanistyka okazuje się często piątym kołem u wozu kończącym na wprost lub nie wprost zdefiniowanym marginesie.
} 
rozstrzygnięć, norm respektowanych przez wszelkie grupy filozofów. Zmienność jej statusu uniemożliwia skonstruowanie obrazu kultury filozofii innego niż bardzo lokalny. Najlepszym przykładem jest sama książka Niżnika, która w kontekście polskim pozostaje (meta)filozoficzna, w kontekście zaś anglosaskim zmieniła przynależność na studia kulturowe ${ }^{12}$. Mówiąc inaczej, wobec tak radykalnego myślenia funkcjonalnego i relacyjnego, przyjęte na wstępie narzędzie rekonstruowania kultury filozofii przestaje działać. Okazuje się niewystarczalne.

\section{Metafilozofia Niżnika - podsumowanie}

Model proponowany przez Józefa Niżnika jest stosunkowo prosty, jednakże wydaje się również najbardziej otwarty. Jeśli moja rekonstrukcja, przeprowadzona z użyciem schematu czterech typów poznania, jest trafna, to oznacza, że posiada on również tę zaletę, że nie tylko przedstawia filozofię (filozofowanie) jako działalność niezwykłą, lecz daje także wystarczająco silne narzędzia, by teza ta miała pokrycie, by w filozofowaniu faktycznie móc dostrzec najbardziej zuchwałe akty poznawcze - redefiniowanie i projektowanie. Z drugiej strony możemy oczekiwać, że inne modele metafilozoficzne niejednokrotnie nie wesprą przeświadczenia o unikalności filozofii koncepcją która roszczenie takie udźwignie i pozwoli dotrzeć do poznania jako redefiniowania i jako projektowania.

Niżnik uważa, że filozofia (filozofowanie) uspójnia ludzkie uniwersum symboliczne poprzez arbitralne akty stwarzania punktów orientacyjnych $\mathrm{w}$ dyskursie. Jako bazowe pojęcia w tym układzie pojawiają się więc: uspójnianie (jako mechanizm oddziaływania aktów filozoficznych na kulturową tkankę), arbitralne akty (i arbitralność jako taka), punkty orientacyjne w dyskursie, rekonstrukcja symbolicznego świata (jego uspójnianie) i struktura sensu (to co załamuje się, a później zostaje odzyskane w wyniku działań filozoficznych).

Jak dotąd moja odpowiedź na wyjściowe pytanie o kulturowe funkcje filozofowania polegała na próbie wysłowienia w kategoriach teorii kultury/socjologii wiedzy tego, co filozofia mówi sama o sobie (w koncepcjach metafilozoficznych). W tym celu w punkcie wyjścia przyjąłem kilka ograniczeń: wybrałem tylko kilka koncepcji metafilozoficznych, sprowadziłem je do krótkich, skondensowanych wypowiedzi, tak aby można było zastosować wobec nich powolną, skrupulatną analizę tekstu po to, by w następnym kroku wyniki tej analizy przeciąć przy pomocy trzech przyjętych narzędzi z teorii kultury: modelu typów poznania, koncepcji kultury danej dziedziny oraz modelu rozwoju profesjonalnych kompetencji. Ta kameralność pracy pozwoliła ugruntować

\footnotetext{
${ }^{12}$ Por. np. stronę wydawnictwa: http://www.thedaviesgrouppublishers.com/niznik\%20arbitrariness.htm, dostęp 20.05.2013. Pod nazwiskiem autora i tytułem książki widnieje wyróżniony z tekstu dopisek: „Contemporary European Cultural Studies”.
} 
rozważania w tekście i oddalić zagrożenie powierzchownością (i tym samym banalnością) uwag na temat roli, znaczenia, czy funkcji filozofii i filozofowania. Modele poddawane analizie zostały tak dobrane, aby wprost lub implicite obejmowały znaczny obszar dorobku filozoficznego, zmniejszając tym samym zagrożenie stronniczości. Przy takiej metodyce pracy nie sposób bowiem rozpatrzyć dużej ilości takich modeli.

Na tym jednak nie koniec. Z grubsza opanowaliśmy już jeden typ perspektywy - co widzą filozofowie, kiedy zamiast przyjmować po prostu ich narzędzia intelektualne, przełożymy ich wizję na ujednolicone narzędzia zaczerpnięte $\mathrm{z}$ teorii kultury i socjologii wiedzy. Pojawia się jednak dalsze pytanie: no dobrze, a jak wyglądają te procesy $\mathrm{w}$ kulturze? Innymi słowy, skończmy z ograniczeniami perspektywy filozofów i wejdźmy głębiej w ich kulturoznawczą translację. Czy, mówiąc jeszcze inaczej: odłóżmy na bok perspektywę filozofów i zobaczmy, co dzieje się z filozofowaniem w kulturze.

Przywołanie kilka akapitów wyżej, w ramach podsumowania, głównych pojęć z modelu Niżnika, miało właśnie umożliwić kolejne kroki. Biorąc bowiem pod uwagę ogólny potencjał poznawczy, przyjmuję jego koncepcję za najbardziej owocny punkt wyjścia dalszych prac. Nie oznacza to, że inne modele są złe, mało obiecujące lub zbyt wąskie.

Kolejnym etapem będzie więc zapytanie: co oznacza podstawowa teza w modelu Niżnika, że filozofia uspójnia ludzkie uniwersum symboliczne? Powyżej udało się przełożyć ją na model czterech typów poznania. To jednak nie mówi nic na temat tego, jak wygląda to w kontekście jakichś szerszych mechanizmów kulturowych. Aby rozwiązać ten problem - wprowadzić więcej teorii kultury tak, by właśnie większa liczba mechanizmów stała się widoczna, a jednocześnie nie stracić z oczu modelu Niżnika, przyjmuję w następnych dwóch częściach książki (Abriszewski, 2013, s. 135-320) metodologię parafrazowania i rozbudowywania: z podstawowej tezy z koncepcji Niżnika wydobywam pojęcie „ludzkiego uniwersum symbolicznego” i pytam, czym ono jest, a następnie czynię to samo z kategorią „uspójniania”. Oznacza to, że jednocześnie muszę przeformułować te pojęcia przy pomocy innych kategorii, a wraz z przeformułowaniem rozbudować cały układ teoretyczny tak, by zobaczyć je w szerszym kontekście.

Podobnie jak dotychczas, przyjmuję (modułową) metodologię składania klocków. Niekiedy można je łączyć razem, innym razem wymieniać. Toteż w następnej części zaproponuję trzy alternatywne ścieżki translacji pojęcia „uniwersum symbolicznego” (Abriszewski, 2013, s. 135-220). Można traktować je równolegle, można spróbować je sklejać, posiadają bowiem pewne cechy wspólne. Każda z nich niesie ze sobą inne zalety i inną perspektywę ogólną.

Teraz jednakże dokonuje się ważny krok: po pierwszym rozeznaniu przyjmuję jako hipotezę bazową dla dalszych analiz, że funkcja filozofowania polega na 
uspójnianiu ludzkiego uniwersum symbolicznego w sytuacjach, kiedy ono tego wymaga. Takie sytuacje potrzeby filozoficznej mogą wiązać się z momentami rozdarć, załamań, wstrząsów, katastrof. Ale może też okazać się, że naturalnym stanem uniwersum symbolicznego jest pewne rozchwianie wymuszające w zupełnie normalnym trybie pracę uspójniania. Więcej, w zależności od przyjętej perspektywy może okazać się, że nieco inaczej wygląda mechanizm uspójniania z perspektywy szerszej panoramy kultury, a inaczej z poziomu jednostki, jeszcze inaczej zaś, kiedy punktem wyjścia nie będą gotowe podmioty (jednostkowe lub zbiorowe), a materialne operacje i przekształcenia albo przepływy i relacje.

\section{Uspójnianie uniwersum symbolicznego i dziury ontologiczne}

W Wyznaniach Świętego Augustyna, w księdze czwartej znajdujemy interesujący opis przyjaźni młodego Augustyna. Przyjaźń kończy się stosunkowo nagle, tragicznie, a na dodatek $\mathrm{w}$ dramatycznych okolicznościach, gdzie umierający tuż przed śmiercią odzyskuje świadomość i nawraca autora Wyznań na właściwą ścieżkę wiary po tym, jak wcześniej obaj solidarnie z niej drwili (Święty Augustyn, 2001, ks. IV, 4). Na swój sposób Augustyn doświadcza dziury ontologicznej, której integralną częścią jest odczucie braku po stracie bliskiego przyjaciela ${ }^{13}$. Pisze on:

Jakimś bólem zamroczone zostało moje serce i na cokolwiek spojrzałem, widziałem śmierć. Męką było dla mnie poruszać się w mieście rodzinnym, niesamowitym smutkiem napawał dom rodzinny. Wszystko, co dzieliłem z przyjacielem, stało się, gdy jego zabrakło, nieznośną torturą (Święty Augustyn, 2001, ks. IV, 4, s. 52).

Trzymając się mechanizmu załamania ładu i jego późniejszego uspójniania, zauważamy u Augustyna rzecz ciekawą - szybkie przesunięcie się w stronę problemów etycznych i ontologicznych, kwestii przyjaźni, tego, czym jest, ale także przywiązania do tego, co doczesne. Mamy tutaj wejście na filozoficzną ścieżkę uspójniania niejako w formie wzorcowej. Oczywista dla nas droga wiodłaby przez roztrząsanie przyczyn choroby, kwestię diagnozy i leczenia, docierając być może do momentu ontologicznego. W przypadku Augustyna mamy

\footnotetext{
${ }^{13} \mathrm{Na}$ fakt, że było to dla Augustyna głębokie i wstrząsające przeżycie zwracają również uwagę autor biografii Augustyn z Hippony Peter Brown (Brown, 1993, s. 58) oraz autor beletryzowanej, choć opatrzonej licznymi przypisami książki o życiu Augustyna Carlo Cremona (Cremona, 1993, s. 32 33). Brown tak komentuje tę sytuację: „Podwójny cios - śmierć przyjaciela, jak i zaakceptowanie przezeń katolickiego chrztu - całkowicie załamał Augustyna” (Brown, 1993, s. 58). Cremona zaś ujmuje to nieco szerzej, podkreślając doświadczenie pustki: „Ileż bólu zadała mi ta strata! - mówi Augustyn. - Byliśmy jedną duszą w dwóch ciałach. Te same przekonania, te same upodobania literackie! Jeden nie mógł żyć bez drugiego. I kiedy umarł - co za pustka we mnie! A miałem już u swego boku kobietę, która urodziła mi Adeodata! Mimo to - pustka! Gdziekolwiek spojrzałem śmierć! Nie mogłem go zobaczyć i rzeczy minione nie mogły już mówić mi o nim. Jak połowa mego życia. Chciałem żyć, żeby i on żył przynajmniej w tej połowie, którą byłem ja; ale jednocześnie pragnąłem śmierci, żeby połączyć się z drugą połową, którą był on” (Cremona, 1993, s. 32-33).
} 
jednak coś na kształt natychmiastowego skoku do ontologicznego basenu - jaka jest relacja między tym, co wieczne, a tym, co doczesne? Jakie jest miejsce człowieka w tym porządku? Autor Wyznań radzi sobie z doświadczeniem dziury ontologicznej w ten sposób, że w osobistej tragedii od razu dostrzega załamanie porządku świata w kategoriach ogólnych.

Tu jednak sprawa wcale jeszcze się nie kończy. Moc tego doświadczenia zdaje się wracać około dziesięciu lat później, gdy mają miejsce wydarzenia z kolejnej księgi, piątej. Przedstawiona zostaje tam ciężka choroba samego Augustyna, która spada na niego po wyjeździe do Rzymu. Choroba jest na tyle poważna, że filozof ociera się o śmierć, „cudem” uchodzi z życiem. I znów, nieco dalej, lecz jeszcze w tej samej księdze piątej, pojawia się kolejny skok w sam środek problematyki ontologicznej, ponieważ Augustyn podnosi zagadnienie relacji między Bogiem i materią oraz między dobrem a złem. Być może tutaj otworzyła się, w inny sposób i w innych okolicznościach, kolejna dziura ontologiczna.

Dziś wiemy, iż ten trop myśli Augustyńskiej okazał się dla historii filozofii i myśli religijnej niezwykle ważny. Dlatego, że zaowocował on oryginalną teodyceą autora Wyznań. Mówiąc inaczej, doświadczenie cierpienia, choroby i śmiertelności własnej i bliskich doprowadziło do przekształcenia osobistego problemu cierpienia i straty $\mathrm{w}$ teoretyczny problem obecności zła w świecie. Teza ontologiczna mówiąca, że zło nie istnieje i jest jedynie brakiem dobra, stała się czymś wyrastającym poza osobiste doświadczenia Augustyna, podobnie jak i cała jego filozofia, która uzyskała status oficjalnej doktryny katolickiej i utrzymała go aż do XIII wieku. Prywatne uspójnienie uniwersum symbolicznego dokonane przez Augustyna stało się uspójnieniem publicznym. Uczyniło pewną częćć świata bardziej zrozumiałą. Augustyn pisząc, że zło jest czymś negatywnym, sam stworzył coś pozytywnego - stworzył punkt orientacyjny, który pozwalał nadać sens pewnemu obszarowi codziennych i niecodziennych doświadczeń.

Jak bardzo trafne w przypadku Augustyna jest pojęcie uspójniania dowodzi krótka rozprawa Paula Ricoeura pod tytułem Zło. Francuski filozof pisze w niej:

To, że filozofia i teologia stają wobec zła jak wobec bezprzykładnego wyzwania, zgodnie, acz nie bez bólu przyznają najwięksi myśliciele tak w jednej, jak w drugiej dyscyplinie. (...)

Problem stanowi tu zakwestionowanie pewnego sposobu myślenia, podległego logicznemu wymogowi spoistości, a więc całości uporządkowanej w sposób niesprzeczny i systematyczny zarazem. (...) Jak można bowiem uznawać za prawdziwe i nie popaść przy tym w sprzeczność takie oto trzy twierdzenia: Bóg jest wszechmogący; Bóg jest absolutnym dobrem; wszelako zło istnieje. Tak przeto teodycea, odpowiadając na zarzut, zgodnie z którym tylko dwa z owych stwierdzeń dają się ze sobą pogodzić, nigdy zaś trzy razem, okazuje się walką toczoną w imię koherencji (Ricoeur, 1992, s. 12). 
Istnieje jednak przeciwwaga dla tych przykładów cierpienia i bólu, które stymulują poszukiwanie punktów orientacyjnych i dokonywanie uspójnień ludzkiego uniwersum symbolicznego. Odnajdziemy ją chociażby w Stowach i rzeczach:

Ta książka zrodziła się z tekstu Borgesa. Ze śmiechu, który w trakcie tej lektury wstrząsa podstawami myślenia, właściwego naszym czasom i naszemu miejscu na świecie - śmiechu podważającego wszelkie uporządkowane płaszczyzny i podziały, które mądrze tłumaczą nam obfitość istnień, podminowującego i na długo pozbawiającego oczywistości naszą tysiącletnią praktykę Tego Samego i Innego (Foucault, 2005, t. 1, s. 8).

Autor Nadzorować i karać wyjaśnia dalej, iż śmiech ten został wywołany przez lekturę osobliwej taksonomii, a dokładniej przez „czystą niemożliwość myślenia w taki sposób" (Foucault, 2005, t. 1, s. 8). Zatem mówi on wprost: niniejsze przedsięwzięcie filozoficzne zostało zainspirowane doświadczeniem niespójności; jeśli wierzyć Foucaultowi, niespójność ta była fundamentalna, znacznie głębsza niż chociażby niespójności wytwarzane przez surrealistów.

Śmiech i cierpienie czy też śmiech i płacz są, jak uczył Helmuth Plessner, reakcjami granicznymi (Plessner, 2004). Czymś, co pojawia się w obliczu całkowitej niemożności poradzenia sobie z sytuacją. Oznaczają one nieprzystawalność naszych zasobów poznawczych do sytuacji. Załóżmy, że tego rodzaju reakcje określają moment, w którym uwewnętrzniony przez jednostkę porządek symboliczny i oczekiwania co do jego kształtu radykalnie zderzają się z faktyczną dynamiką otaczającego świata, gdy ład wokół załamuje się, a mapa poznawcza za nim nie nadąża. Przypuśćmy, że pierwsza reakcja jest somatyczna - śmiech albo płacz (lub jedno i drugie na raz), ale zaraz potem, w następnym momencie uruchamia się mechanizm łatający właśnie otwartą dziurę ontologiczną. Ten mechanizm łatający to właśnie akt filozofowania, który czasami staje się na tyle oryginalny i jednocześnie na tyle skutecznie zaczyna krążyć po świecie kultury, że trafia na dobre do jej zasobów. Uchwyceniu tego właśnie mechanizmu poświęcona są Kulturowe funkcje filozofowania.

\section{Bibliografia}

Abriszewski, K. (2013). Kulturowe funkcje filozofowania. Toruń: Wydawnictwo Naukowe Uniwersytetu Mikołaja Kopernika.

Augustyn. (2001). Wyznania. Tłum. ks. J. Czubaj, Warszawa: De Agostini Polska.

Berger, P., \& Luckmann, Th. (1983). Społeczne tworzenie rzeczywistości. Tłum. J. Niżnik, Warszawa: Państwowy Instytut Wydawniczy.

Brown, P. (1993). Augustyn z Hippony. Tłum. W. Radwański. Warszawa: Państwowy Instytut Wydawniczy. 
Cremona, C. (1993). Augustyn z Hippony. Rozum i wiara. Tłum. M. Serejska-Wróbel. Warszawa: Wydawnictwo Księży Marianów.

Foucault, M. (2005). Słowa i rzeczy. Tłum. T. Komendant, Gdańsk: Słowo/obraz terytoria.

Kołakowski, L. (2000). Kultura i fetysze. Warszawa: Wydawnictwo Naukowe PWN SA.

Marquard, O. (1994). Rozstanie z filozofia pierwszych zasad. Tłum. K. Krzemieniowa, Warszawa: Oficyna Naukowa.

Mikurda, K. (2015). Nie-całość. Žižek, Dolar, Zupančič. Warszawa: PWN.

Morgan, E. (2010). Blizny po ewolucji: co nasze ciała mówią nam o pochodzeniu człowieka. Tłum. M. Danicka-Kosut, Warszawa: Anadiomene.

Niżnik, J. (1999). Arbitralność filozofii, Warszawa: IFiS PAN.

Nowak, L. (1998). Byt i myśl. U podstaw negatywistycznej metafizyki unitarnej. Tom I. Nicość i istnienie. Poznań: Zysk i S-ka Wydawnictwo.

Plessner, H. (2004). Śmiech i płacz. Badania nad granicami ludzkiego zachowania. Tłum. A. Zwolińska \& Z. Nerczuk, Kęty: Antyk.

Ricoeur, P. (1992). Zło. Wyzwanie rzucone filozofii i teologii. Tłum. E. Burska, Warszawa: Instytut Wydawniczy PAX.

Siemek, M. J. (1982). Filozofia, dialektyka, rzeczywistość. Warszawa: Państwowy Instytut Wydawniczy.

Wallerstein, I. (2004). Koniec świata jaki znamy. Tłum. M. Bilewicz, A. Jelonek \& K. Tyszka, Warszawa: Wydawnictwo Naukowe SCHOLAR.

Zybertowicz, A. (1995). Przemoc i poznanie. Studium z nie-klasycznej socjologii wiedzy. Toruń: Wydawnictwo UMK.

Žižek, S. (2012). Less Than Nothing. Hegel and the Shadow of Dialectical Materialism. London, New York: Verso.

Žižek, S. (2014). Event. Penguin Books. 


\title{
To clash with common sense and to patch up cultural holes: philosophical culture in the works of Leszek Nowak and Józef Niżnik
}

\begin{abstract}
The article raises the question of cultural function of philosophy and acts of philosophizing. The argument that follows reinterprets Leszek Nowak's and Józef Niżnik's metaphilosophical theories as philosophical culture, i.e. the essential features of philosophy indicated by Nowak and Niżnik, are viewed as relatively common presuppositions about philosophy shared by philosophers (implicitly or explicitly). In this way, viewing philosophy as cultural game leads to the question of what kind of epistemological-cultural game philosophy would be. I address the question by referring to Andrzej Zybertowicz's model of four types of epistemological-cultural games: reproduction, discovery, redefinition, and design. In the final part of the text, I follow Niżnik's idea that the function of philosophy is to patch up cracks (which I dub "ontological holes) in human symbolic universe and briefly analyze two examples from history of philosophy of such breaks that lead to development of fully fledged philosophical stances.
\end{abstract}

Keywords: philosophizing; metaphilosophy; culture of philosophy; common sense; patch up cracks; ontological holes; human symbolic universe 